\title{
Effects of substitution of tricaprylin or coconut oil for tallow in milk replacers offered to preruminant lambs
}

\section{B. Aurousseau ${ }^{1}, M$. Vermorel ${ }^{1}, M$. Theriez $^{2}$ and A. Vezinhet ${ }^{3}$}

with the technical assistance of F. Duboisset, J.P. Donnat, Y. Garambois, S. Gasnet, M. Martinaud, G. Moins and R. Souchet

1 INRA, laboratoire d'étude du métabolisme énergétique, CRZV Theix, 63122 Ceyrat;

2 INRA, laboratoire de production ovine INRA - CRZV Theix, 63122 Ceyrat;

${ }^{3}$ Ecole Nationale Supérieure Agronomique, laboratoire de physiologie animale, centre de recherches de Montpellier, 9 Place Viala, 34060 Montpellier Cedex, France

(received 25 October 1988, accepted 15 March 1989)

Summary - The effects of tricaprylin or coconut oil on the digestibility of milk-substitute constituents, nitrogen balance, growth-rate and feed efficiency before weaning have been studied in 2 successive trials using 12 male Charmois (trial 1) and 20 male Limousin and Romanov $x$ Limousin preruminant lambs (trial 2).

In trial 1,3 different diets $\left(C_{1}, T_{1} a, T_{1} b\right)$ containing 230,161 or $92 \mathrm{~g}$ tallow and 0,69 or $138 \mathrm{~g}$ tricaprylin per $\mathrm{kg}$ dry matter (DM) were prepared. Digestibility of the milk-substitutes was studied in 2- and 3-week-old lambs, and growth-rate and feed efficiency were studied up to weaning.

In trial 2, 3 other diets $\left(\mathrm{C}_{2}, \mathrm{CO}_{2}\right.$ and $\left.\mathrm{T}_{2}\right)$ containing 249,166 or $166 \mathrm{~g}$ tallow, 0,83 or $0 \mathrm{~g}$ coconut oil, and 0,0 or $93 \mathrm{~g}$ tricaprylin per $\mathrm{kg} \mathrm{DM}$, were prepared. They were used for digestibility and nitrogen balance determination in 3- and 6-week-old lambs. Growth rates and feed efficiency were obtained between 10 days and weaning.

In trial 1, the level of intake was 14 and $29 \%$ higher in lambs fed T1a and T1b than in lambs fed C1. Apparent digestibility of the diets was significantly higher $(P<0.05)$ after tricaprylin substitution for part of the tallow. The extent of the effect increased with the level of tricaprylin $(P<0.025)$. Mean apparent respective digestibilities of energy and nitrogen were $0.907,0.947$ or 0.971 and 0.924 , 0.961 or 0.972 , growth rates 195,265 or $282 \mathrm{~g} /$ day $(P<0.05)$ and feed efficiency 670,797 or $725 \mathrm{~g}$ gain $/ \mathrm{kg} D M$ intake, respectively with $\mathrm{C}_{1}, \mathrm{~T}_{1}$ a or $T_{1} b$ milk substitutes.

In trial 2, tricaprylin intake did not have any effect; coconut oil led to a slight increase in nitrogen digestibility, but only in 6-week-old lambs (from 0.970 to $0.979 ; P<0.05$ ). Mean apparent respective digestibilities of energy and nitrogen were $0.967,0.969$ or 0.972 and $0.965,0.971$ or 0.967 respectively for $\mathrm{C}_{2}, \mathrm{CO}_{2}$ or $\mathrm{T}_{2}$. Coconut oil diet led to a 13 or $19 \%(P<0.01)$ higher nitrogen balance respectively in 3- or 6-week-old lambs; tricaprylin resulted in a slight increase of nitrogen balance in 3-week-old lambs $(+11 \%, P<0.10)$. Growth-rates and feed efficiency were respectively 179,211 or $199 \mathrm{~g} /$ day and $25.8,26.7$ or $27.0 \mathrm{~g}$ gain/MJ GE for $\mathrm{C}_{2}, \mathrm{CO}_{2}$ or $\mathrm{T}_{2}$.

preruminant lamb - tricaprylin — coconut oil 
Résumé - Effets de la substitution de tricapryline ou d'huile de coprah à une partie du suif dans les aliments d'allaitement offerts a des agneaux préruminants. Les effets de l'incorporation de tricapryline ou d'huile de coprah à des laits de remplacement sur leur utilisation digestive, la fixation d'azote dans les tissus, la vitesse de croissance des agneaux et l'efficacité alimentaire avant sevrage ont été étudiés au cours de 2 études successives mettant en jeu 12 agneaux mâles préruminants de race charmoise (essai 1) et 20 agneaux mâles préruminants de race Limousine ou Romanov $x$ Limousine (essai 2).

Dans l'essai 1,3 régimes différents $\left(C_{1}, T_{1} a, T_{1} b\right)$ comportant 230, 161 ou $92 \mathrm{~g}$ de suif et 0,69 ou $138 \mathrm{mg}$ de tricapryline par $\mathrm{kg}$ de matière sèche (MS), ont été préparés. La digestibilité de ces laits de remplacement a été mesurée à 2 et à 3 semaines et la croissance des agneaux et l'efficacité alimentaire étudiées jusqu'au moment du sevrage.

Dans l'essai 2, 3 autres régimes $\left(\mathrm{C}_{2}, \mathrm{CO}_{2}\right.$ et $\left.T_{2}\right)$ comportant 249,166 ou $166 \mathrm{~g}$ de suif, 0,83 ou O $\mathrm{g}$ d'huile de coprah, et 0,0 ou $93 \mathrm{~g}$ de tricapryline par $\mathrm{kg} \mathrm{MS}$, ont été préparés. La digestibilité et le bilan de l'azote ont été mesurés à 3 et à 6 semaines. La vitesse de croissance des agneaux et l'efficacité alimentaire ont été étudiées entre le dixième jour et le moment du sevrage.

Dans l'essai 1, les agneaux ont consommé respectivement 12 et $49 \%$ de plus avec les aliments $T_{1} a$ et $T_{1} b$ qu'avec l'aliment $C_{1}$. La digestibilité a augmenté de façon significative avec la quantité de tricapryline substituée à du suif de l'aliment de départ $(P<0,05)$, elle est passée de 0,907 à 0,947 ou 0,971 pour l'énergie et de 0,924 à 0,961 ou 0,972 pour l'azote, respectivement dans le cas des régimes $C_{1}, T_{1} a$ et $T_{1} b$. Les vitesses de croissance ont été de 195, 265 ou 282 g/jour $(\mathrm{P}<$ $0,05)$ et l'efficacité alimentaire 670,797 ou $725 \mathrm{~g}$ gain $/ \mathrm{kg}$ MS ingérée.

Dans l'essai 2, l'utilisation de tricapryline n'a eu aucun effet significatif sur la digestibilité. L'incorporation d'huile de coprah dans les aliments a permis d'accroître légèrement la digestibilité de l'azote, mais seulement en sixième semaine (de 0,970 à 0,$979 ; \mathrm{P}<0,05$ ). La digestibilité apparente moyenne a été de $0,967,0,969$ ou 0,972 pour l'énergie et de $0,965,0,971$ ou 0,967 pour l'azote, respectivement avec les régimes $\mathrm{C}_{2}, \mathrm{CO}_{2}$ ou $T_{2}$. L'aliment contenant l'huile de coprah a conduit à une augmentation de 13 ou de $19 \%(\mathrm{P}<0,01)$ de la fixation d'azote dans les tissus, respectivement à 3 ou à 6 semaines. Avec laliment contenant la tricapryline la fixation d'azote a légèrement augmenté à 3 semaines (11\%; $\mathrm{P}<0,10)$. Les vitesses de croissance et l'efficacité

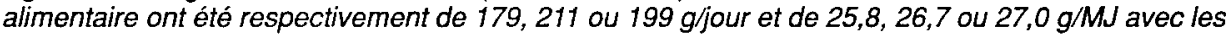
aliments $\mathrm{C}_{2}, \mathrm{CO}_{2}$ ou $T_{2}$.

agneau préruminant - tricapryline - huile de coprah

\section{INTRODUCTION}

Many newborn lambs are small for date, due to underfeeding of ewes bearing multiple foetuses (Alexander, 1974; Robinson et al., 1977; Tissier \& Theriez, 1978) and must be weaned and reared with milk replacers because the ewes cannot provide enough milk for 3 or 4 lambs. The small for date lambs need specific feedstuffs more readily digested than triglycerides of long-chain fatty acids. Carbohydrates cannot be used by the organism of the newborn without limitation, and excess can lead to digestive or metabolic disorders (Walker \& Faichney, 1964; Glimp, 1972), but medium chain triglycerides (MCT) are more easily disposed of in the digestive tract of domestic newborn mammals, being readily hydrolysed in the stomach under the action of salivary lipases and partially absorbed in this organ (Leat \& Harrison, 1975; Perret, 1980) and completely hydrolysed and absorbed in the intestine (Walker \& Stokes, 1970; Gibney \& Walker, 1977).

Application of coconut oil in the constitution of milk replacers offered to the preruminant lamb has been beneficial for the growth of the lambs and for the composition of adipose tissue at slaughter (Aurousseau et al., 1973), but leads to deposition of higher amounts of adipose 
tissue (Theriez et al., 1973). A purified MCT, tricaprylin (TC8), has been shown to sustain adequate growth for long periods in the rat (Harkins \& Sarett, 1968; Saxena et al., 1972) in the preruminant calf (Namiotkevicz, 1973; Aurousseau et al., 1984), or in the infant (Gracey et al., 1970; Guy-Grand \& Bour, 1970; Tantibhedhyangkul \& Hashim, 1975). The rapid and efficient digestion of MCT is followed by a rapid oxidative catabolism (Perret, 1980; Jensen et al., 1986), and therefore MCT appear as an interesting source of energy for the small for date lamb. However, the usual mixture of MCT is not always well tolerated by the organism of the infant (Okamoto et al., 1982; Henderson \& Dear, 1986). Some adverse effects on animal health have also been reported in the calf given MCT (from margarine or pure $\mathrm{C} 8$ and $\mathrm{C10}$ ) rich diets (Roy et al., 1973), but we did not observe such trouble in two consecutive experiments on the same animal (Aurrouseau et al., 1984a, 1984b).

The effects of MCT on nitrogen balance and feed efficiency are also disputed. Some observations thus showed increased nitrogen deposition and feed efficiency in the organism of the newborn mammals with tricaprylin (Harkins \& Sarett, 1968; Aurousseau \& Vermorel, 1971, in the rat; Namiotkevicz, 1973; Aurousseau et al., 1984b, in the calf; Ghadimi et al., 1973; Putet \& Senterre, 1983; Senterre et al., 1983, in the infant). Others showed no effect other than a decreased energy deposition (Newport et al., 1979, in the pig; Huston et al., 1983, in the infant).

We therefore developed a series of experiments intended to investigate the effects of tricaprylin intake on milk digestion, energy utilisation, nitrogen balance and feed efficiency at different ages.

\section{MATERIALS AND METHODS}

\section{Milk replacers}

In a preliminary experiment (trial 1), 3 different diets $\left(C_{1}, T_{1} a, T_{1} b\right)$ with a protein content and $a$ lipid content of 259 and $230 \mathrm{~g} / \mathrm{kg}$ dry matter (DM) respectively, were prepared.

In a further experiment (trial 2), 3 other diets $\left(\mathrm{C}_{2}, \mathrm{CO}_{2}, \mathrm{~T}_{2}\right)$, with a protein and a lipid content of 263 and of $249 \mathrm{~g} / \mathrm{kg} \mathrm{DM}$, respectively, were used.

Tallow was the unique source of fat in $C_{1}$ and $\mathrm{C}_{2}$, and was partially replaced by tricaprylin in $\mathrm{T}_{1} \mathrm{a}$ and $\mathrm{T}_{2}(30 \%)$ and in $\mathrm{T} 1 \mathrm{~b}$ $(60 \%)$, or by coconut oil in $\mathrm{CO}_{2}(30 \%)$. The different ingredients were mixed and incorporated by means of spray drying in both trials, except for tricaprylin in trial 1 added as such in the liquid diet. The composition of the different diets is given in Table I. The liquid milk was reconstituted in each instance at a rate of $160 \mathrm{~g}$ $\mathrm{DM} / \mathrm{kg}$.

\section{Animals and management}

The synopsis of the 2 successive trials is given in Table II. Trial 1 involved the utilization of 12 male Charmois preruminant lambs, on which digestion studies were carried out at 2 and 3 weeks, and which were thereafter suckled in groups up to weaning.

Trial 2 involved the utilization of 20 male preruminant lambs used, after being allowed to adapt to artificial rearing in groups, for digestion and nitrogen balance determinations at 3 weeks of age (10 purebred Limousin and 10 crossbred Romanov $\times$ Limousin), and at 6 weeks ( 6 lambs of each breed).

The lambs were weaned from the ewe after being allowed to suckle their mother for $24 \mathrm{~h}$. In trial 1 , they were fitted with the equipment for faeces collection and installed in small wooden pens, as described by Brisson et al. (1970). In trial 2, the lambs, fitted with the same equipment, were installed in metallic pens, and urine was collected in flasks containing $100 \mathrm{ml}$ $6 \mathrm{~N}$ sulfuric acid (to prevent any ammonia loss), with the help of rigid plastic funnels held under the wire floor of the crates. Crate floors and funnels were washed twice daily and 
Table I. Milk constituents ( $\mathrm{g} / \mathrm{kg} \mathrm{DM})$.

\begin{tabular}{|c|c|c|c|c|c|c|}
\hline \multirow{2}{*}{$\begin{array}{l}\text { Trial } \\
\text { Diet }\end{array}$} & \multicolumn{3}{|c|}{1} & \multicolumn{3}{|c|}{2} \\
\hline & $c_{1}$ & $T_{1} a$ & $T_{1} b$ & $c_{2}$ & $\mathrm{CO}_{2}$ & $T_{2}$ \\
\hline $\begin{array}{l}\text { Skim milk powder } \\
\text { Tallow }\end{array}$ & $\begin{array}{l}736 \\
230\end{array}$ & $\begin{array}{l}736 \\
161\end{array}$ & $\begin{array}{r}736 \\
92\end{array}$ & $\begin{array}{l}717 \\
249\end{array}$ & $\begin{array}{l}717 \\
166\end{array}$ & $\begin{array}{l}707 \\
166\end{array}$ \\
\hline Coconut oil & - & - & - & - & 83 & - \\
\hline Tricaprylin & - & 69 & 138 & - & - & 93 \\
\hline Emulsifier & 14 & 14 & 14 & 14 & 14 & 14 \\
\hline $\begin{array}{l}\text { Lactic ferment and mineral } \\
\text { and vitamin supplements (1) }\end{array}$ & 20 & 20 & 20 & 20 & 20 & 20 \\
\hline
\end{tabular}

(1) $4 \mathrm{~g} \mathrm{Mg} \mathrm{Cl}_{2} 6 \mathrm{H}_{2} \mathrm{O} ; 50 \mathrm{mg} \mathrm{Fe} \mathrm{SO}$. $7 \mathrm{H}_{2} \mathrm{O} ; 50 \mathrm{mg} \mathrm{ZnO} ; 50 \mathrm{mg} \mathrm{Mn} \mathrm{SO}{ }_{4}-4 \mathrm{H}_{2} \mathrm{O} ; 20 \mathrm{mg} \mathrm{Cu} \mathrm{SO}$. $5 \mathrm{H}_{2} \mathrm{O} ; 8 \mathrm{mg} \mathrm{Kl}$; $0.6 \mathrm{mg} \mathrm{Co} \mathrm{Cl} ; 3.6 \mathrm{mg}$ vitamin $\mathrm{A} ; 240 \mathrm{mg}$ vitamin $\mathrm{D} ; 50 \mathrm{mg}$ vitamin $\mathrm{E} ; 2 \mathrm{mg}$ vitamin $\mathrm{K} ; 2 \mathrm{mg}$ vitamin $\mathrm{B} 1 ; 4 \mathrm{mg}$ vitamin $\mathrm{B} 2 ; 2 \mathrm{mg}$ vitamin $\mathrm{B} 6 ; 0.05 \mathrm{mg}$ vitamin $\mathrm{B} 12 ; 0.75 \mathrm{mg}$ biotin $2 \mathrm{mg}$ calcium pentothenate; $1.8 \mathrm{~g}$ choline; $50 \mathrm{mg}$ furazolidone.

Table II. Synopsis of the whole set of trials.

Trial

Breed of lamb

Diet

Animal No.

Milk dry matter (DM \%)

Energy ( $\mathrm{kJ} / \mathrm{g} \mathrm{DM})$

Nitrogen (mg/g DM)

Digestibility measurements

1

Southdown

T1a

C1

4

16.5

20.7

41.4

4

16.7

20.4

41.4

2nd and 3rd weeks
2

Limousin and

Romanov $x$ Limousin

a Nitrogen balance determination.

* Growth and feed efficiency after weaning (not yet reported) were also studied.

representative samples of urine and water used for washing were taken for analysis.

Milk substitute was offered ad libitum in flasks equipped with nipples fitted with plastic tubing which reached to the bottom of the flasks. Fresh milk was offered twice daily. The amounts of milk offered and refused were controlled, and representative samples of the milk and refusals were gathered every day for analysis. The lambs were also weighed at birth, at the beginning and at the end of the digestion periods, and in trial 1 every week thereafter. 


\section{Chemical and mathematical analysis}

Milk refusal and faeces were freeze-dried and the dry weight controlled after equilibration in air-tight dessicators under vacuum. An additional correction for dry matter content was obtained after heat drying the powders for $48 \mathrm{~h}$ at $80^{\circ} \mathrm{C}$. Energy content was obtained with the help of a Gallenkamp adiabatic calorimeter and lipid content of the ingesta was determined gravimetrically after extraction according to the method of Folch et al. (1957). Nitrogen was determined on the same samples as well as on urine and wash water according to the Kjeldahl method. Statistical analysis of data involved 3 and 4 factor variance analysis (Snedecor \& Cochran, 1971) and the use of non-parametric tests according to the procedure of Kruskal \& Wallis (1952) and Mann \& Witney (Schwartz, 1969).

\section{RESULTS}

\section{Food intake, live weight gain and feed efficiency}

In trial 1, compared to the values obtained in lambs fed $C_{1}$, feed intakes were 12.4 and $29.6 \%$ higher respectively in lambs fed $T_{1} a$ and $T_{1} b$ (Fig. 1). The Kruskal and Wallis test showed a dose-dependent effect of tricaprylin in 2- and 3-week-old lambs. Statistical analysis could not be performed in the following period, since lambs were fed in groups after the third week. Growth rates of the lambs fed tricaprylin were significantly $(P<0.05)$ enhanced $(+35$ and $+44.6 \%$ respectively in lambs fed $T_{1} a$ and $T_{1} b$ compared to lambs fed $T_{1}$ ), as was feed efficiency ( +20 and $+8 \%$ respectively)

In trial 2 however, only minor differences in food intake were observed between lambs fed $\mathrm{C}_{2}, \mathrm{CO}_{2}$ and $\mathrm{T}_{2}$ (Table III). However, no significant differences were observed between growth rates or feed efficiency in lambs fed $\mathrm{C}_{2}, \mathrm{CO}_{2}$ or $\mathrm{T}_{2}$ diets (Table III).

\section{Digestibility of the diets}

Analysis of the data according to the Kruskal-Wallis test and to the MannWhitney U-test showed that in trial 1 (Table IV), except for nitrogen digestibility in 3-week-old lambs offered T1a diet, tricaprylin significantly $(P<0.05)$ increased the apparent digestibility of diet constituents, by 2.2 to 5.1 points in the case of $\mathrm{T} 1 \mathrm{a}$, or by 4.5 to 6.6 points in the case of T1b diet. Moreover, increasing the level of tricaprylin led to significant $(P<$ 0.05 ) increases in energy digestibility in 2week-old lambs and of DM, energy and nitrogen digestibility in 3-week-old lambs.

The digestibilities of DM, energy and nitrogen from $\mathrm{C}_{2}, \mathrm{CO}_{2}$ and $\mathrm{T}_{2}$ milks were very homogenous (Table IV), and, except for a slight increase in nitrogen digestibility in 6-week-old lambs fed the

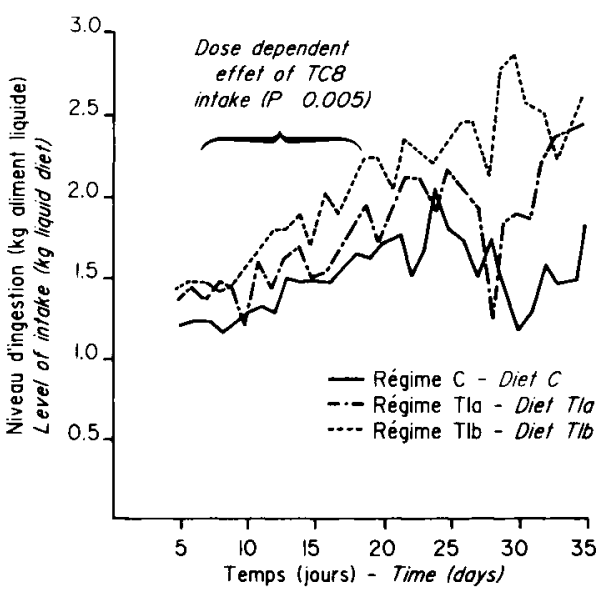

Fig. 1. Effect of the type of diet on the level of intake (after 15 days, the lambs were fed in groups, and no statistical analysis could be performed). 
Table III. Intake, growth rate and feed efficiency from day 10 to day 35 of the trial (mean and SD).

\begin{tabular}{|c|c|c|c|c|c|c|}
\hline \multirow{2}{*}{$\begin{array}{l}\text { Trial } \\
\text { Diet }\end{array}$} & \multicolumn{3}{|c|}{1} & \multicolumn{3}{|c|}{2} \\
\hline & C1 & T1a & $T 1 b$ & $C 2$ & $\mathrm{CO} 2$ & $T 2$ \\
\hline $\begin{array}{l}\text { Lamb number } \\
\text { Live weight at } 10 \text { days }(\mathrm{kg}) \\
\text { Live weight gain }(\mathrm{g} / \mathrm{day}) \\
\text { Dry matter intake ( } \mathrm{g} / \mathrm{day}) \\
\text { Feed efficiency }\end{array}$ & $\begin{array}{c}4 \\
4.7 \pm 0.6 \\
195 \pm 25 a \\
303\end{array}$ & $\begin{array}{c}4 \\
4.4 \pm 0.6 \\
265 \pm 19 b \\
346\end{array}$ & $\begin{array}{c}4 \\
4.6 \pm 0.7 \\
282 \pm 27 b \\
405\end{array}$ & $\begin{array}{c}4 \\
6.2 \pm 0.9 \\
179 \pm 41 \\
305 \pm 51\end{array}$ & $\begin{array}{c}4 \\
6.1 \pm 0.8 \\
211 \pm 32 \\
355 \pm 15\end{array}$ & $\begin{array}{c}4 \\
6.2 \pm 0.6 \\
199 \pm 23 \\
325 \pm 25\end{array}$ \\
\hline $\begin{array}{l}\text { g gain } / \mathrm{kg} \mathrm{DM} \\
\text { g gain/MJ GE } \\
\text { g gain/g protein }\end{array}$ & $\begin{array}{l}670 \\
32.4 \\
2.59\end{array}$ & $\begin{array}{l}797 \\
39.1 \\
3.08\end{array}$ & $\begin{array}{l}725 \\
36.1 \\
2.80\end{array}$ & $\begin{array}{c}582 \pm 31 \\
25.8 \pm 1.4 \\
2.26 \pm 0.12\end{array}$ & $\begin{array}{c}595 \pm 78 \\
26.7 \pm 3.5 \\
2.26 \pm 0.30\end{array}$ & $\begin{array}{c}608 \pm 29 \\
27.0 \pm 1.3 \\
2.31 \pm 0.11\end{array}$ \\
\hline
\end{tabular}

Table IV. Effect of substitution of tricaprylin or coconut oil for part of the tallow on milk constituent digestibility (1) at different ages in the preruminant lamb (2).

\begin{tabular}{|c|c|c|c|c|c|}
\hline \multirow[t]{2}{*}{ Milk constituent } & \multirow[t]{2}{*}{ Trial } & \multirow[t]{2}{*}{ Diet } & \multicolumn{2}{|c|}{ Age of lambs (weeks) } & \multirow[b]{2}{*}{6} \\
\hline & & & 2 & 3 & \\
\hline \multirow[t]{2}{*}{ Dry matter } & 1 & $\begin{array}{l}C_{1} \\
T_{1} a \\
T_{1} b\end{array}$ & $\begin{array}{l}92.5 \pm 1.1(\mathrm{a}) \\
96.5 \pm 0.4(\mathrm{~b}) \\
97.3 \pm 0.4(\mathrm{~b})\end{array}$ & $\begin{array}{l}93.8 \pm 1.1(\mathrm{a}) \\
96.0 \pm 0.3(\mathrm{~b}) \\
98.3 \pm 0.3(\mathrm{c})\end{array}$ & - \\
\hline & 2 & $\begin{array}{l}\mathrm{C}_{2} \\
\mathrm{CO}_{2} \\
\mathrm{~T}_{2}\end{array}$ & - & $\begin{array}{l}96.7 \pm 0.3 \\
96.9 \pm 0.3 \\
97.7 \pm 0.3\end{array}$ & $\begin{array}{l}97.0 \pm 0.3 \\
97.7 \pm 0.3 \\
97.0 \pm 0.5\end{array}$ \\
\hline \multirow[t]{2}{*}{ Energy } & 1 & $\begin{array}{l}C_{1} \\
T_{1} a \\
T_{1} b\end{array}$ & $\begin{array}{l}90.0 \pm 1.3(\mathrm{a}) \\
95.1 \pm 0.4(\mathrm{~b}) \\
96.6 \pm 0.4(\mathrm{c})\end{array}$ & $\begin{array}{l}91.3 \pm 1.5(\mathrm{a}) \\
94.3 \pm 0.5(\mathrm{~b}) \\
97.6 \pm 0.5(\mathrm{c})\end{array}$ & - \\
\hline & 2 & $\begin{array}{l}\mathrm{C}_{2} \\
\mathrm{CO}_{2} \\
\mathrm{~T}_{2}\end{array}$ & - & $\begin{array}{l}96.0 \pm 0.3 \\
95.5 \pm 0.3 \\
96.7 \pm 0.3\end{array}$ & $\begin{array}{l}97.4 \pm 0.3 \\
97.2 \pm 0.3 \\
96.7 \pm 0.5\end{array}$ \\
\hline \multirow[t]{2}{*}{ Nitrogen } & 1 & $\begin{array}{l}\mathrm{C}_{1} \\
\mathrm{~T}_{1} \mathrm{a} \\
\mathrm{T}_{1} \mathrm{~b}\end{array}$ & $\begin{array}{l}91.5 \pm 1.5(\mathrm{a}) \\
96.3 \pm 0.4(\mathrm{~b}) \\
96.4 \pm 0.3(\mathrm{~b})\end{array}$ & $\begin{array}{l}93.2 \pm 1.6(a) \\
95.9 \pm 0.3(a) \\
97.9 \pm 0.3(b)\end{array}$ & - \\
\hline & 2 & $\begin{array}{l}\mathrm{C}_{2} \\
\mathrm{CO}_{2} \\
\mathrm{~T}_{2}\end{array}$ & - & $\begin{array}{l}95.9 \pm 0.3 \\
96.3 \pm 0.3 \\
96.7 \pm 0.4\end{array}$ & $\begin{array}{l}97.0 \pm 0.3(\mathrm{a}) \\
97.9 \pm 0.3(\mathrm{~b}) \\
96.6 \pm 0.3(\mathrm{a})\end{array}$ \\
\hline
\end{tabular}

(1) Apparent digestibility coefficients, mean \pm SEM. (2) Trial 1, $n=4$; trial $2, n=7$ in 3-week-old lambs, $n=4$ in 6 week-old lambs. a, b, $c=$ within a given trial and at a given age, data followed by different letters are signiticantly different $(P<0.05)$. 
CO2 diet, were not influenced by the type of lipid or the breed of the lambs. However, age had a significant effect $(P<$ 0.005 ) on nitrogen digestibility and significant interactions between age and type of milk $(P<0.025)$ were observed for energy digestibility (Table IV).

\section{Nitrogen balance (trial 2)}

The following relationships were observed between nitrogen balance (NB, $\mathrm{g} \mathrm{d}^{-1}$ per $\mathrm{kg} \mathrm{W0.75),} \mathrm{metabolizable} \mathrm{energy} \mathrm{intake}$ (ME, $\mathrm{J} \mathrm{d}^{-1}$ per $\mathrm{kg} \mathrm{W}^{0.75}$ ), and age of the lambs $(A, d)$ :

with $\mathrm{C} 2$

$\mathrm{NB}=22.9 \mathrm{ME}-0.161 \mathrm{ME} . \mathrm{A}-0.16$ (1)
(SD 5.6) (SD 0.033) (SD 17.9)

(Sres 0.11); $\left(r^{2}=0.837\right)$

with $\mathrm{CO}_{2}$

$\mathrm{NB}=17.9 \mathrm{ME}-0.270 \mathrm{ME} . \mathrm{A}-0.24$ (2)

(SD 2.2) (SD 0.065)

(SD 10.8)

(Sres 0.07); $\left(r^{2}=0.961\right)$

with $\mathrm{T} 2$

$\mathrm{NB}=24.4 \mathrm{ME}-0.139 \mathrm{ME} . \mathrm{A}-0.27$ (3)

(SD 4.4) (SD 0.066)

(SD 13.5)

(Sres 0.11); $\left(r^{2}=0.890\right)$

Compared to the values obtained in the case of lambs fed $\mathrm{C} 2$, adjusted nitrogen balances (Table $\mathrm{V}$ ), were thus increased by 13.5 or $18.8 \%(P<0.01)$ in lambs fed $\mathrm{CO}_{2}$, respectively in 3- or 6week-old lambs, or by $11.1(P<0.01)$ or $5.5 \%$ (NS) in lambs fed T2 diet.

Table V. Trial 2. Effects of substitution of coconut oil $\left(\mathrm{CO}_{3}\right)$ or tricaprylin (T3) for tallow in the milk offered to 3- or 6-week-old preruminant lambs on nitrogen balance (means and SD).

\begin{tabular}{|c|c|c|c|c|c|c|}
\hline $\begin{array}{l}\text { Age of the lambs (week) } \\
\text { Diet }\end{array}$ & $c_{2}$ & $\begin{array}{l}3 \\
\mathrm{CO}_{2}\end{array}$ & $T_{2}$ & $c_{2}$ & $\begin{array}{l}6 \\
\mathrm{CO}_{2}\end{array}$ & $T_{2}$ \\
\hline No. of lambs & 7 & 7 & 6 & 4 & 4 & 4 \\
\hline Age (d) & $\begin{array}{l}18.0 \\
(3.4)\end{array}$ & $\begin{array}{l}18.6 \\
(2.1)\end{array}$ & $\begin{array}{l}18.1 \\
(2.1)\end{array}$ & $\begin{array}{l}38.3 \\
(2.4)\end{array}$ & $\begin{array}{l}39.8 \\
(1.7)\end{array}$ & $\begin{array}{l}39.8 \\
(1.5)\end{array}$ \\
\hline Liveweight (kg) & $\begin{array}{r}8.2 \\
(1.0)\end{array}$ & $\begin{array}{r}8.2 \\
(1.1)\end{array}$ & $\begin{array}{r}8.0 \\
(0.9)\end{array}$ & $\begin{array}{l}13.1 \\
(0.9)\end{array}$ & $\begin{array}{l}14.6 \\
(0.9)\end{array}$ & $\begin{array}{l}13.7 \\
(1.9)\end{array}$ \\
\hline$M E$ intake $(M J / d)$ & $\begin{array}{r}6.33 \\
(0.65)\end{array}$ & $\begin{array}{r}6.07 \\
(0.62)\end{array}$ & $\begin{array}{c}6.21 \\
(0.59)\end{array}$ & $\begin{array}{r}6.31 \\
(0.95)\end{array}$ & $\begin{array}{r}8.36 \\
(0.83)\end{array}$ & $\begin{array}{r}7.66 \\
(1.25)\end{array}$ \\
\hline Nitrogen balance $(\mathrm{g} / \mathrm{d})$ & $\begin{array}{r}6.247 \\
(0.454)\end{array}$ & $\begin{array}{r}6.685 \\
(0.601)\end{array}$ & $\begin{array}{r}7.025 \\
(0.788)\end{array}$ & $\begin{array}{r}5.712 \\
(1.630)\end{array}$ & $\begin{array}{r}7.412 \\
(1.091)\end{array}$ & $\begin{array}{r}6.888 \\
(1.184)\end{array}$ \\
\hline Adjusted $N$ balance $(\mathrm{g} / \mathrm{d})^{*}$ & 6.145 & 6.975 & 6.829 & 6.188 & 7.352 & 6.505 \\
\hline
\end{tabular}

* Data ajusted for a mean age of 18.0 days, a mean liveweight of $8.1 \mathrm{~kg}$, and a mean ME intake of $6.2 \mathrm{MJ} / \mathrm{d}$ in $3-$ week-old lambs, or 39.3 days, $13.8 \mathrm{~kg}$ and $7.44 \mathrm{MJ} / \mathrm{d}$ in 6 -week-old lambs, according to the relationships given in the text. 


\section{DISCUSSION}

The increase in feed intake observed in trial 1 with tricaprylin rich diets was not obtained in trial 2. These contradictory results can be compared to the effects that we obtained previously with tricaproin (Aurousseau, 1984) : an increase in feed intake was observed with high levels of proteins in the diet $(320 \mathrm{~g} / \mathrm{kg} \mathrm{DM})$ but not with moderate levels (260 $\mathrm{g} / \mathrm{kg}$ DM). Similarly, coconut oil ( $30 \%$ of the total fat) did not alter food intake, as opposed to the results obtained previously (Theriez et al., 1973). Apparently, increases in food intake were observed only when the design of the wooden crates, in which 6 lambs were facing each other, allowed for emulation in suckling the milk replacers.

Tricaprylin effect on milk constituent digestibility was obvious only in trial 1 . In that case, control milk digestibility was lower $(0.90-0.93)$ than previously observed (0.947-0.957, Theriez et al., $1973)$ or than in trial $2(0.959-0.974)$. However, Bouchard \& Brisson (1970) reported similar values $(0.88-0.92)$. This low tallow digestibility was not explained by different $\mathrm{C} 18: 0$ or C18:1 contents, but may be due to a poor emulsification in trial 1. Replacement of a poorly digestible energy source (tallow) by a highly digestible one (tricaprylin being entirely hydrolysed and absorbed in the digestive tract of the lamb according to Walker \& Stokes, 1970 or Gibney \& Walker, 1977) was thus likely to increase efficiently energy digestibility. This was not the case in trial 2, where the digestibility of tallow was already high. According to this result, due to a reproducible high digestibility, tricaprylin application to the milk substitutes fed to newborn animals would appear to be more reliable than conventional milk substitutes, the digestibility of which can achieve relatively low values.
However, the effects of tricaprylin intake on milk constituent digestibilities were not as clear-cut as the effects of tricaproin (Aurousseau et al., 1983b).

As already described for coconut oil (Walker \& Stokes, 1970; Theriez et al., 1973) or tricapoin (Aurousseau et al., 1983b), tricaprylin (trial 1) or coconut oil (trial 2) incorporation also increased nitrogen digestibility (Table IV). Medium chain triglyceride hydrolysis in the stomach of the preruminant animal, facilitating a more pronounced degradation of protein of the milk clot has been put forward to explain this phenomenon (Ternouth et al., 1975). Caprylic acid has also been reported to alter membrane organization and facilitate absorption of large molecules (Kajii et al., 1986). Changing the redox state of the mitochondria by easily metabolized substrates can also lead to an increase in the energy flux in the intestinal cell (Kimura \& Warshaw, 1988), which could facilitate the energy-linked absorption of amino acids.

In trial 2, substitution of coconut oil for part of the tallow in the milk increased nitrogen balance both in 3- or in 6-weekold lambs $(+13.5$ or $+18.8 \%$ respectively). The effects were of the same order as those $(+12.6$ to $+13.2 \%)$ observed in the preruminant calf (Aurousseau et al., 1983a, 1984b). Substituting tricaprylin for a similar amount of tallow than in the case of coconut oil led to a lower effect on nitrogen balance $(+11.1$ and +5.5 respectively in 3- or 6-week-old lambs), as previously observed in calves (Aurousseau et al., 1984). The effect of tricaprylin on nitrogen balance also appeared lower than the previously reported effect of tricaproin (Aurousseau, 1988). The decrease in the effect of tricaprylin when the lambs grew older, compared well with the effects of "tallow-coconut oiltricaprylin" milk replacers on the rate of 
growth in calves, stimulated only over a period of 5 weeks (Aurousseau et al., 1984a).

Finally, the $19 \%$ increase in feed efficiency observed in lambs fed $\mathrm{T1a}$ compared to lambs fed $\mathrm{C}_{1}$ diet compared well with the $15 \%$ increase observed previously in lambs fed a "coconut-oil" milk replacer compared to lambs fed a conventional "tallow" milk replacer (Thierez et al., 1973). Similar differences of level of intake were obtained in both experiments, but those differences are not likely to play a major role in feed efficiency, since increases in level of intake $(+10$ to $+40 \%)$ did not alter feed efficiency in previously reported results (Molenat et al., 1971; Penning et al., 1973). The absence of any effect of type of milk on feed efficiency in trial 2 is more difficult to understand, since significant positive effects on nitrogen balance were obtained.

\section{CONCLUSION}

These results confirm the interest of the application of medium chain fatty acids to the nutrition of the small for date lamb. Caprylic acid, as previously reported for coconut oil and for caproic acid, is well tolerated by the newborn lamb, and can allow for an increase in level of food intake, has an efficient digestibility and can increase deposition of body protein and growth rate of the lambs during the first part of their life, as does coconut oil.

The adverse effects on health reported in some infants were not seen in any of the lambs used, but the effects of caprylic acid were not as clear-cut as those obtained with caproic acid, which had already been observed in preruminant calves. More information on the effects of these components on the metabolism of the different tissues is needed to explain why molecular species, differing only by a 2-carbon unit and otherwise presenting very close metabolic features, finally lead to noticeably different effects on diet digestibility or growth.

The high price of pure MCFA makes them more suitable for infant feeding. However, the positive contribution of coconut oil in regard to the nutrition of the small for date lamb born from multiple fœus-bearing ewes should not be disregarded.

\section{REFERENCES}

Alexander G. (1974) Birthweight of lambs : influences and consequences. In : Size at Birth, Ciba Fond. Symp. 27, 215-239

Aurousseau B. (1984) Effets combinés de l'apport d'acide caproíque et de la concentration en protéines sur l'utilisation de laits artificiels par l'agneau préruminant. II. Croissance et composition corporelle des agneaux. Ann. Zootech. 33, 201-218

Aurousseau B. (1988) Effects of substitution of tricaproin for tallow and of protein concentration in milk substitutes on nitrogen and energy balance in the preruminant lamb. Br. J. Nutr. $60,525-538$

Aurousseau B. \& Vermorel M. (1971) Caprylic acid utilization by growing rats at two different physiological states. Nutr. Rep. Int. 4, 95-102

Aurousseau B., Theriez M. \& Daniel M. (1973) Influence de la nature des matières grasses incorporées dans l'aliment d'allaitement sur le métabolisme lipidique de l'agneau de boucherie. Ann. Biol. Anim. Bioch. Biophys. 13, 93-105

Aurousseau B., Vermorel M. \& Bouvier J.C. (1983a) Influence du remplacement d'une partie du suif d'un aliment d'allaitement par de la tricaproine ou de l'huile de coprah par l'utilisation de l'énergie et de l'azote par le veau préruminant; influence du niveau d'alimentation antérieur. Reprod. Nutr. Dev. 23, 587-597 
Aurousseau B., Vermorel M. \& Theriez M. (1983b) Effets combinés de l'apport d'acide caproique et de la concentration en protéines sur l'utilisation de laits artificiels par l'agneau préruminant. I. Utilisátion digestive des principaux constituants du régime. Ann. Zootech. 32, 441-458

Aurousseau B., Thivend P. \& Vermorel M. (1984a) Influence du remplacement d'une partie du suif d'un aliment d'allaitement par de la tricaproine ou de la tricapryline en association à de l'huile de coprah sur la croissance du jeune veau préruminant. Ann. Zootech. 33, 219-234

Aurousseau B., Vermorel M. \& Bouvier J.C. (1984b) Influence du remplacement d'une partie du suif d'un aliment d'allaitement par de la tricapryline ou de l'huile de coprah sur l'utilisation de l'énergie et de l'azote par le veau préruminant. Reprod. Nutr. Dev. 24, 265-279

Bouchard P. \& Brisson G.J. (1970) Tallow versus corn-oil in a milk substitute for artificially reared lambs and digestibility of diet constituents. J. Anim. Sci. 31, 804-809

Brisson G.J., Bouchard R. \& Morisset-Rochette M. (1970) Equipment for nutritional studies with lambs weaned at 3 days of age and reared on experimental diets. J. Anim. Sci. 31, 417-421

Folch J., Lees M. \& Sloane-Stanley G.M. (1957) A simple method for the isolation and purification of total lipids from animal tissues. J. Biol. Chem. 226, 497-509

Ghadimi H., Arulanantham K. \& Rathi M. (1973) Evaluation of nutritional management of the low birth-weight newborn. Am. J. Clin. Nutr. 26, 473-476

Gibney M.J. \& Walker D.M. (1977) Milk replacers for preruminant lambs : protein and fat interactions. Aust. J. Agric. Res. 28, 703712

Glimp H.A. (1972) Effect of diet composition on performance of lambs reared from birth on milk replacer. J. Anim. Sci. 34, 1085-1088

Gracey M., Burke V. \& Anderson C.M. (1970) Medium chain triglycerides in pediatric practice. Arch Dis. Child. 45, 445-452

Guy-Grand B. \& Bour H. (1970) Intérêt des triglycérides à chaine moyenne en diététique clinique. Bull. Acad. Natl. Med. 154, 11-12

Harkins R.W. \& Sarett H.P. (1968) Nutritional evaluation of medium chain triglycerides in the rat. JAOCS 45, 26-30

Henderson M.J. \& Dear P.R.F. (1986) Dicarboxylic aciduria and medium-chain triglyceride supplemented milk. Arch. Dis. Childh. 6, 610-611

Huston R.K., Reynolds J.W., Jensen C. \& Buist N.R.M. (1983) Nutrient and mineral retention and vitamin $\mathrm{D}$ absorption in low birth-weight infants : effect of medium chain triglycerides. Pediatrics 72, 44-48

Jensen C., Buist N.R.M. \& Wilson T. (1986) Absorption of individual fatty acids from long chain or medium chain triglycerides in very small infants. Am. J. Clin. Nutr. 43, 748-751

Kajii H., Horie T., Hayasmi M. \& Awazu S. (1986) Effects of drug absorption on isolated rat small intestinal epithelial cells. Int. J. Pharmacol. 33, 253-255

Kimura R.E. \& Warshaw J.B. (1988) Control of fatty acid oxidation by intramitochondrial $\mathrm{NADH} / \mathrm{NAD}^{+}$in developing rat small intestine. Pediatr. Res. 23, 262-265

Kruskal W.H. \& Wallis W.A. (1952) Use of ranks in one-criterium variance analysis. J. Am. Stat. Assoc. 47, 583-621

Leat W.M.F. \& Harrison F.A. (1975) Digestion, absorption and transport of lipids in the sheep. In: Digestion and Metabolism in the Ruminant (McDonald I.W. \& Warner A.C.I., eds), The University of New England Publishing Unit, Armidale, pp. 481-495

Molenat G., Theriez M. \& Aguer D. (1971) L'allaitement artificiel des agneaux. I. Determination de l'âge minimal au sevrage pour la production d'agneaux de boucherie. Ann. Zootech. 20, 339-352

Namiotkevicz J. (1973) L'utilisation des acides gras synthétiques pour l'engraissement des veaux. Rocz. Nauk. Roln. B94, 7-16

Newport M.J., Storry J.E. \& Tuckley B. (1979) Artificial rearing of pigs. VII. Medium chain triglycerides as a dietary source of energy and their effect on live weight gain, feed : gain ratio, carcass composition and blood lipids. $B r . J$. Nutr. 41, 85-93

Okamoto E., Muttart C.R., Zucker C.L. \& Heird W.C. (1982) Use of medium-chain triglycerides in feeding the low birth weight infant. Am. $J$. Dis. Childh. 136, 428-431

Penning P.D., Cottrell K.M. \& Treacher T.T. (1973) The effects of quantity and distribution of milk substitute on the performance of artificially reared lambs to forty-eight days of age. Anim. Prod. 17, 179-186

Perret J.P. (1980) Gastric lipolysis of maternal milk TG and gastric absorption of MCFA in the young rabbit. J. Physiol. 76, 159-166 
Putet G. \& Senterre J. (1983) Nutrient deposition in low birth-weight infants. In: Nutritional Adaptation of the Gastrointestinal Tract of the Newborn (Kretcher N. \& Minkowski A., eds), Vevey/Raven Press, New York, pp. 177-183

Robinson J.J., McDonald I., Fraser C. \& Crofts R.M.J. (1977) Studies on reproduction in prolitic ewes. I. Growth of the products of conception. J. Agric. Sci. Camb. 88, 539-552

Roy J.H.B., Stobo I.J.F., Gaston H.J., Shotton S.M. \& Ganderton P. (1973) The nutrition of the veal calf. VI. The effect of ultra high (68 per cent) fat milk powders added to liquid skim milk and a comparison with spray dried milk powder containing 20 p.100 margarine fat. Anim. Prod. 17, 109-127

Saxena S.C., Wendelmans-Starrenburg A. \& Vles R.O. (1972) Effects of feeding medium chain triglycerides to rats for 13 weeks. Nutr. Metab. 14, 362-370

Schwartz D. (1969) Les tests non paramétriques : buts et principaux tests. In : Méthodes Statistiques à I'Usage des Médecins et Biologistes. Flammarion Médecine Science, Paris, 3rd edn, pp. 245-247

Senterre J., Putet G., Sallee R. \& Rigo J. (1983) Effects of vitamin D and phosphorus supplementation on calcium retention in preterm infants fed banked human milk. J. Pediatr. 103, 305-307

Snedecor G.W. \& Cochran W.G. (1957) Statistical Methods. Transl. by Boelle H. \&
Cammajt E., 1971. Assoc. Coordin. Tech. Agric., Paris, 6th edn, pp. 524-559

Tantibhedhyankul P. \& Hashim S.A. (1975) Medium-chain triglyceride feeding in premature infants : effects on fat and nitrogen absorption. Pediatrics 55, 359-370

Ternouth J.H., Roy J.H.B., Thompson S.Y., Toothill J., Gillies C.M. \& Edwards-Webb J.D. (1975) Concurrent studies of the flow of digesta in the duodenum and exocrine pancreatic secretion of calves. III. Further studies on the addition of fat to skim milk and the use of non milk protein in milk substitute. Br. J. Nutr. 31, 181-196

Theriez M., Molenat G., Daniel M. \& Aurousseau B. (1973) L'allaitement artificiel des agneaux. III. Influence de la nature des matières grasses incorporées dans l'aliment d'allaitement. Ann. Zootech. 22, 185-197

Tissier M. \& Theriez M. (1978) Influence du niveau des apports énergétiques distribués à la brebis pendant la gestation sur le poids de naissance et la croissance des agneaux. Ann. Biol. Anim. Biochim. Biophys. 19, 235-240

Walker D.M. \& Faichney G.J. (1964) Nutritional diarrhoea in the milk-fed lamb and its relation to the intake of sugar. Br. J. Nutr. 18, 209-215

Walker D.M. \& Stokes G.B. (1970) The nutritive value of fat in the diet of the milk fed lamb. 1 . The apparent and corrected digestibilities of different fats and their constituent fatty acids. Br. J. Nutr. 24, 425-433

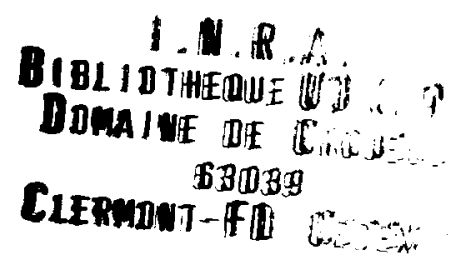

